\title{
Response of Wheat Genotypes to Different Levels of Nitrogen
}

\author{
Shukra Raj Shrestha ${ }^{1 *}$, Sarita Manandhar ${ }^{1}$, Bedanand Chaudhary ${ }^{1}$, Bibek Sapkota ${ }^{2}$, Rudra Bhattarai ${ }^{1}$ and Surya Prasad Adhikari ${ }^{1}$ \\ ${ }^{1}$ Regional Agricultural Research Station, Sunsari \\ ${ }^{2}$ Socio-economics and Agricultural Research Policy Division, Khumaltar, Nepal \\ "Correspondence: shukrarajshrestha@gmail.com
}

Received January 2016; Revised September 2016; Accepted October 2016

Scientific Editors: Yagya G. Khadka, Bhava P. Tripathi

Copyright @2016 NARC. Permits unrestricted use, distribution and reproduction in any medium provided the original work is properly cited

\begin{abstract}
ABSRACT
A field experiment was conducted for two years using six genotypes of wheat (Triticum aestivum L.) for response to different levels of nitrogen (N) use. The experiment was laid out in split plot design with four levels $\left(0,50,100\right.$ and $\left.150 \mathrm{~kg} \mathrm{~N} \mathrm{ha}^{-1}\right)$ as main plots and six wheat genotypes (BL 3623, BL 3629, BL 3872, NL 1008, NL 1055 and Vijay, a check variety) as sub-plots. Grain yield and other yield components increased linearly in response to $\mathrm{N}$ concentrations in both seasons. Only two parameters: days to heading (DOH) and days to maturity (DTM) varied significantly $(\mathrm{p} \leq 0.05)$ among wheat genotypes in both the years. None of the parameters showed interaction effects in both seasons. Vijay showed highest grain yield of $3.12 \mathrm{t} \mathrm{ha}^{-1}$ in 2013 with the application of $100 \mathrm{~kg} \mathrm{~N} \mathrm{ha}^{-1}$, and $3.23 \mathrm{t} \mathrm{ha}^{-1}$ in $2014 \mathrm{with}_{150 \mathrm{~kg} \mathrm{~N} \text { ha }}^{-1}$. Spike length, productive tillers $\mathrm{m}^{-2}$, number of spikes $\mathrm{m}^{-2}$ and test weight were greater with higher $\mathrm{N}$ rates. The straw yield of wheat fertilized with $150 \mathrm{~kg} \mathrm{~N}$ $\mathrm{ha}^{-1}$ was the highest in Vijay $\left(4.35 \mathrm{t} \mathrm{ha}^{-1}\right)$ and BL $3872\left(4.33 \mathrm{t} \mathrm{ha}^{-1}\right)$, respectively. Vijay with $100 \mathrm{~kg} \mathrm{~N}^{-1}$ produced the highest number of productive tillers $\mathrm{m}^{-2}$ (276.33) in 2013 and 296.00 with the application of $150 \mathrm{~kg} \mathrm{~N}^{-1}$ in 2014.
\end{abstract}

Keywords: Nitrogen levels, wheat genotypes, yield

\section{सारांश}

गहुँका ६ वटा उन्मोचन योग्य जातहरुमा माटोमा नाईट्रोजनको विभिन्न मात्रा राखी दुई बर्ष सम्म उत्पादन र उत्पादकत्वको अध्ययन गरियो । उक्त परीक्षण Split Plot Design मा संचालन गर्दा मुख्य प्लटहरुमा नाईट्रोजनको चारवटा मात्राहरु (०, ४०, १०० र १५० के. जी. नाईट्रोजन प्रति हे.) र सहायक प्लटहरुमा गहुँको ६ वटा जातहरु (बी. एल. ३६२३, बी. एल. ३६२९, बी. एल. ३६७२, एन. एल. १००६, एन. एल.१०४४ र विजय छरिएको थियो। दानाको उत्पादन र उत्पादनमा सघाउने आयामहरु परिक्षण गर्दा बढ़दो नाईट्रोजनको दुवै वर्षहरुमा समानान्तर असर देखियो। दुई वटा मापदण्डहरु पसाउने दिन र पाक्ने दिनहरु दुवै वर्षहरुमा जातहरु पिच्छे, तथ्याड़ीय रुपमा फरक देखिए। दुवै वर्षहरुमा सम्पूर्ण मापदण्डहरुमा गहुँका जातहरु र नाईट्रोजनको मात्राहरु बीच कुनै तथ्याड़ीय अन्तरसम्बन्ध देखिए। सन् २०१३ मा १०० के.जी. नाईट्रोजन प्रति हे. प्रयोग गर्दा बिजय जातले ३.१२ टन प्रति हे. उत्पादन भएको पाईयो, भने सन् २०१४ मा १४० के.जी. नाईट्रोजन प्रति हे. को दरले प्रयोग गर्दा सोही जातको उत्पादकत्व ३. २३ टन प्रति हे. पाइयो। बालाको लम्बाई, प्रति वर्ग मि. मा रहेको उत्पादनमूलक गाँजहरुको संख्या, प्रति वर्ग मि. मा रहेको बालाहरुको संख्या र हजार दानाहरुको तौल बढ़दो नाइट्रोजनका मात्रा संगै वृद्धि भएको पाइयो। दुवै वर्षहरुमा १४० के. जी नाइट्रोजन प्रति हे. प्रयोग गर्दा विजय जातले $४$.३५ टन प्रति हे. र बी. एल ३६७२ जातले ४.३३ टन प्रति हे. सबैभन्दा बढी परालको उत्पादन भएको पाइयो। सन २०१३ मा विजय जातमा १०० के. जी नाइट्रोजन प्रति हे. प्रयोग गर्दा सबैभन्दा वढी उत्पादनमूलक गाँजहरु २७६. ३३ र सोही जातले सन २०१४ मा १४० के.जी. नाईट्रोजन प्रति हे. को दरले प्रयोग गर्दा सबैभन्दा बढ़ी उत्पादनमूलक २९७ गाँजहरु भएको पाइयो।

\section{INTRODUCTION}

Wheat is the third most important crop in terms of production in Nepal (Joshi 2015, Bhattarai et al 2015). Its area, production and yield were 7,54,243 ha, 17,27,346 $\mathrm{t}$ and $2.29 \mathrm{t} \mathrm{ha}^{-1}$, respectively (MoAD 2013). In Sunsari district located in eastern Nepal, the productivity of wheat was $2.6 \mathrm{t} \mathrm{ha}^{-1}$ in 2013 (DADO 2012/13). Since the wheat plays major role in human food and nutrition, thus after the entry of semi-dwarf wheat varieties, the trend of introducing advanced breeding lines has increased in Nepal. Despite of that, the production of wheat remained stagnant with a clear yield gap between national average and farmers' field (MoAD 2012/13). In addition, high variation could be observed among wheat genotypes with respect to phonological traits and responses to fertilizer application. The stagnant yield and gap could be caused by several reasons (NWRP 2012). One primary reason could be inappropriate and inadequate fertilization- thus, it is necessary to know the response of fertilizers among wheat genotypes for increasing production. Nitrogen $(\mathrm{N})$ is generally the most common major limiting nutrient for growth and yield of crops worldwide (Camara et al 2003). The supply of nutrients in a suitable form is also a major determining factor for cereal production with $\mathrm{N}$ being the most important applied fertilizer (Spiertz 1984), as wheat is very sensitive to insufficient $\mathrm{N}$ and very responsive to $\mathrm{N}$ fertilization. $\mathrm{N}$ is one of the most important agronomic factors affecting the yield and technological quality, especially protein content, gluten amount and quality (Podolska 2014).

It should be noted that both an optimized $\mathrm{N}$ management for a less responsive cultivar and a restrictive management for a more demanding cultivar may result in crops with little yield potential (Rusell et al 2014). High nutrient levels can also harm crops by making wheat plants more vulnerable to lodging (Ma et al 2010) and economic losses to farmers, because only $33 \%$ of all $\mathrm{N}$ fertilizers applied to cereal crops are absorbed in harvested grains (Raun and Johnson 1999). Thus, the use of $\mathrm{N}$ in wheat crops must be optimized to increase yields. There are reports of $\mathrm{N}$ use in wheat crops, ranging from 90 to $225 \mathrm{~kg} \mathrm{ha}^{-1}$ of $\mathrm{N}$, without significant responses in grain yield under more favorable environment and management conditions (Barraclough et al 2010). For irrigated wheat, Heinemann et al (2006) observed a positive response up to $156 \mathrm{~kg} \mathrm{ha}^{-1}$ of $\mathrm{N}$, with a grain yield of $6472 \mathrm{~kg} \mathrm{ha}^{-1}$. So undoubtedly, $\mathrm{N}$ deficiency constitutes one of the major yield limiting factors for cereal production (Sarwar et al 2012).

Numerous researchers found that more $\mathrm{N}$ was demanded by modern wheat varieties, which is typically supplied in the form of $\mathrm{N}$ fertilizers (Campbell et al 1993, Wagen et al 2003 and Salvagiotti and Miralles 2008). The effectiveness of N depends on many factors 
mainly the term of $\mathrm{N}$ applications and the variety (Podolska 2014). There are several studies on the use of $\mathrm{N}$ fertilizers and wheat production in Nepal (Rai and Khadka 2009, NWRP 2012, Bhattari et al 2015). However, in present work we elucidate the response of wheat genotypes to different levels of $\mathrm{N}$ fertilizers applied for the selection of most promising genotypes.

\section{MATERIALS AND METHODS}

Two field experiments were conducted during November-April of 2012/13 and 2013/14 on a clay loam soil at RARS, Tarahara (Figure 1). The GPS coordinates of experimental site is $26.7069^{\circ} \mathrm{N}$ latitude and $087.2813^{\circ} \mathrm{E}$ longitudes lying at 127 masl. The experiment was laid out in a split plot design with four nitrogen levels $\left(0,50,100\right.$ and $\left.150 \mathrm{~kg} \mathrm{~N} \mathrm{ha}^{-1}\right)$ as main plots and six wheat genotypes (BL 3623 , BL 3629, BL 3872, NL 1008, NL 1055 and Vijay) as sub-plots. Every treatment was replicated three times for a total of seventy two plots of $2 \mathrm{~m} \times 5 \mathrm{~m}=\left(10 \mathrm{~m}^{2}\right)$.

All other cultivation practices were uniform for all treatments. Composite soil samples from each block of the experiment were taken from the upper $25 \mathrm{~cm}$ depth before sowing. Land was thoroughly ploughed to make the soil well pulverized. Seed sowing was done on 30 November in both the years. Spacing was maintained $25 \mathrm{~cm}$ between rows and plot consisted of eight continuous rows of $5 \mathrm{~m}$ long. $\mathrm{N}$ was provided through urea and Diammonium phosphate (DAP). Phosphorus (P) was applied through DAP, but in no-nitrogen plot, the source of $\mathrm{P}$ was Single Super Phosphate and the source of potassium was Muriate of potash (MOP). Whole dose of P and potassium $(\mathrm{K})$ were applied at the time of land preparation. Half $\mathrm{N}$ was applied in line at the time of sowing and the remaining half was broadcasted with the first irrigation at 25 DAS (days after sowing).

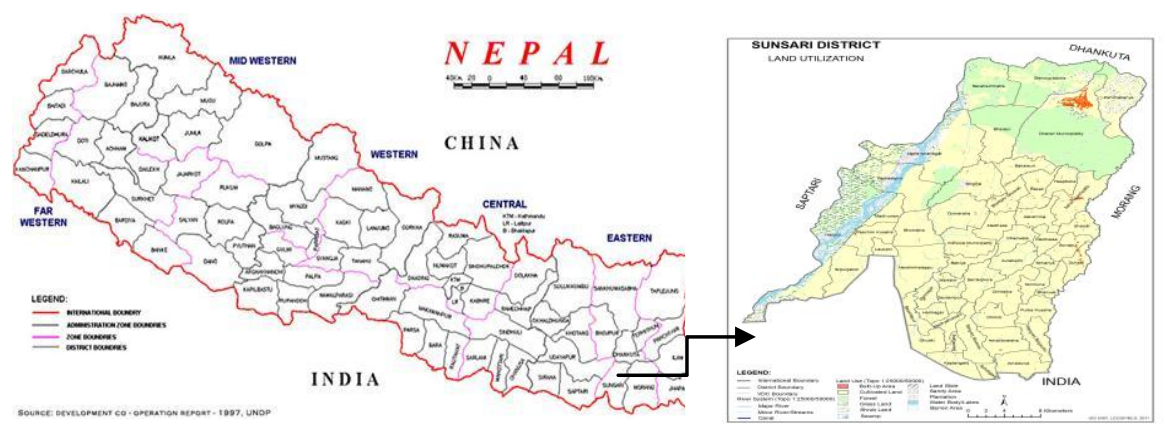

Figure1. Location of the experimental site at RARS, Tarahara, Sunsari, Nepal.

The parameters recorded were (Table 1); emergence count $\mathrm{m}^{-2}$, days to heading, days to maturity, plant height ( $\mathrm{cm}^{-}$, productive tillers $\mathrm{m}^{-}$ ${ }^{2}$, spike length $(\mathrm{cm})$, number of spikes $\mathrm{m}^{-2}$, test weight $(\mathrm{g})$, grain yield $\left(\mathrm{t} \mathrm{ha}^{-1}\right)$ and straw yield $\left(\mathrm{t} \mathrm{ha}^{-1}\right)$. Grain and straw was brought from whole $10 \mathrm{~m}^{2}$ for the measurement. Straw was sun dried for a day and weighed while grain weight was estimated at $14 \%$ moisture. The measured weight of grain and straw were converted into hectare basis. The meteorological data was obtained from weather station that is supervised by Dharan based Department of Hydrology and Meteorology, Government of Nepal established at RARS, Tarahara. The methods adopted for the laboratory analysis has been given in Table 1. The soil characteristic of the experimental sites has been presented in Table 2. Data collected during the experiment were analyzed using MSTAT statistical package. The Duncan's multiple range (DMR) test at $5 \%$ probability level was used to test the differences among mean values.

Table 1. Parameters and methods adopted for the laboratory analysis at RARS, Tarhara

\begin{tabular}{lll}
\hline SN & Parameter & Method \\
\hline 1 & pH & Potentiometric 1:2 (Jackson 1973) \\
2 & Soil Organic Matter (\%) & Walkely and Black (Walkely and Black 1934) \\
3 & Total N (\%) & Kjeldahl (Bremner and Mulvaney 1982) \\
4 & Available P $\left(\mathrm{kg} \mathrm{ha}^{-1}\right)$ & Olsen (Olsen et al1954) \\
5 & Available K $\left(\mathrm{kg} \mathrm{ha}^{-1}\right)$ & Ammonium acetate (Jackson 1967) \\
6 & Soil texture (Particle size analysis) & Hydrometer (Bouyoucos 1927) \\
\hline
\end{tabular}

Table 2. Soil characteristics of experimental site at RARS Tarahara, Nepal

\begin{tabular}{lcc}
\hline Characteristics & $\mathbf{2 0 1 2}$ & $\mathbf{2 0 1 4}$ \\
\hline $\mathrm{pH}$ & 7.2 & 6.5 \\
Soil organic matter $(\%)$ & 4.1 & 3.7 \\
Total N $(\%)$ & 0.12 & 0.17 \\
Available P $\left(\mathrm{kg} \mathrm{ha}^{-1}\right)$ & 119 & 115 \\
Available K $\left(\mathrm{kg} \mathrm{ha}^{-1}\right)$ & 136 & 119 \\
Soil texture (Particle size analysis) & Clay loam & Clay loam \\
\hline
\end{tabular}



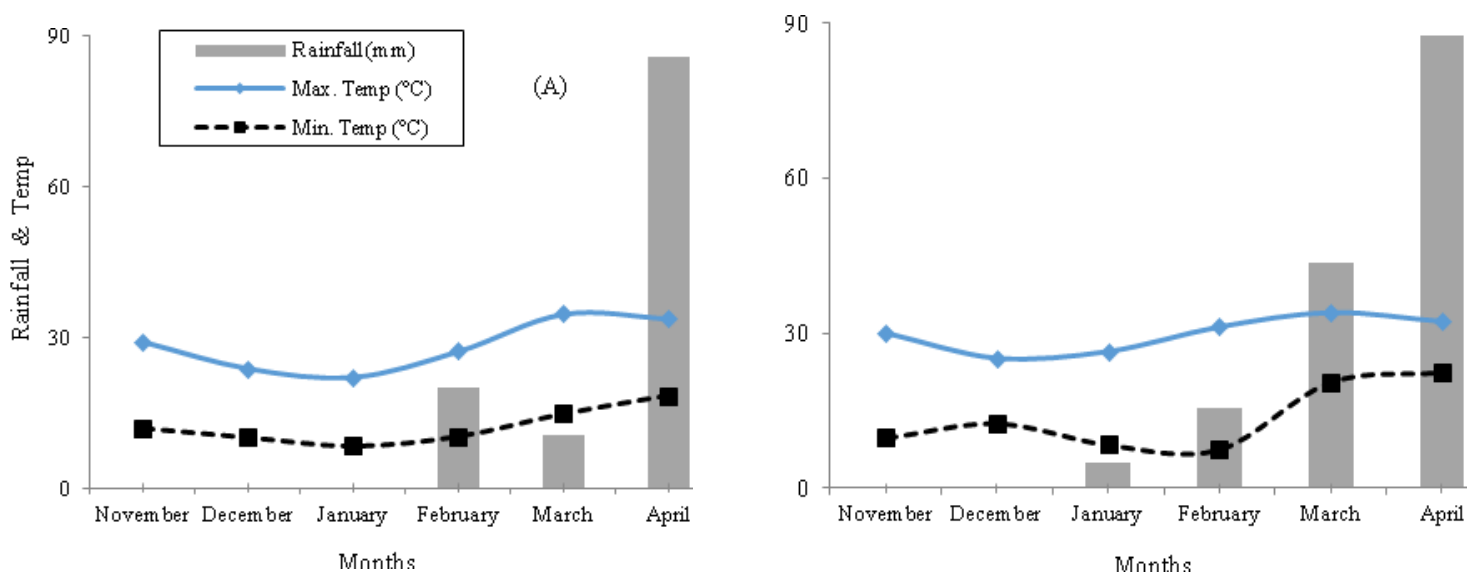

Figure 2. Meteorological data for the year 2013 (A) and 2014 (B) at RARS, Tarahara, Nepal.

\section{RESULTS}

The meteorological data of the study area has been presented in Figure 2. Mainly three parameters were monitored, rainfall pattern, minimum and maximum air temperature (Figure 2). The patter of rainfall was almost similar in both the years, however, in 2014 there was slightly earlier rainfall even in the month of January, comparative to 2013 the rainfall in 2014 was slightly higher in the months of March and April, while the pattern of minimum and maximum air temperature was almost similar in both years lowest in January in 2013 and February in 2014. N application significantly $(\mathrm{p} \leq 0.05)$ affected all parameters tested in both the years (Table 3). Of all the parameters, days to heading (DTH) and days to maturity (DTM) significantly $(\mathrm{p} \leq 0.05)$ varied among six wheat genotypes in both the years. In both years, BL 3872 took the maximum days to heading ranging from 87.92 to 89.82 days. The maximum days to maturity (120) was observed in NL 1055 in 2013, while BL 3872 took the maximum days to maturity (126.5) in 2014. The effect of interaction between $\mathrm{N}$ and wheat genotypes on all parameters during both the years was not significant $(\mathrm{p} \leq 0.05)$.

Table 3. Growth, yield and yield components of wheat genotypes under different levels of nitrogen in 2013 at RARS, Tarahara, Nepal

\begin{tabular}{|c|c|c|c|c|c|c|c|c|c|c|}
\hline Treatments & $\begin{array}{l}\text { Emergence } \\
\text { count } \mathrm{m}^{-2}\end{array}$ & $\begin{array}{l}\text { Days to } \\
\text { heading }\end{array}$ & $\begin{array}{l}\text { Days to } \\
\text { maturity }\end{array}$ & $\begin{array}{l}\text { Plant } \\
\text { height } \\
\text { (cm) }\end{array}$ & $\begin{array}{l}\text { Productive } \\
\text { tillers } \mathrm{m}^{-2}\end{array}$ & $\begin{array}{l}\text { Spike } \\
\text { length } \\
\text { (cm) }\end{array}$ & $\begin{array}{l}\text { Spikes } \\
\text { m }^{-2}\end{array}$ & $\begin{array}{l}\text { Test weight } \\
\text { (g) }\end{array}$ & $\begin{array}{l}\text { Grain } \\
\text { yield (t } \\
\left.\text { ha }^{-1}\right)\end{array}$ & $\begin{array}{l}\text { Straw } \\
\text { yield (t } \\
\left.h^{-1}\right) \\
\end{array}$ \\
\hline \multicolumn{11}{|l|}{$\begin{array}{l}\mathbf{N} \text { levels } \\
\mathrm{N}_{0}\end{array}$} \\
\hline & $130.6^{\mathrm{c}}$ & $79.5^{\mathrm{c}}$ & $107.7^{\mathrm{c}}$ & $77.74^{\mathrm{c}}$ & $143.6^{\mathrm{c}}$ & $8.33^{\mathrm{b}}$ & $149.4^{\mathrm{d}}$ & $38.64^{\mathrm{d}}$ & $1.67^{\mathrm{c}}$ & $2.28^{\mathrm{c}}$ \\
\hline $\mathrm{N}_{1}$ & $141.4^{\mathrm{b}}$ & $84.44^{\mathrm{b}}$ & $115.2^{\mathrm{b}}$ & $84.68^{b}$ & $164.6^{\mathrm{b}}$ & $9.46^{\mathrm{a}}$ & $167.8^{\mathrm{c}}$ & $41.20^{c}$ & $2.30^{\mathrm{b}}$ & $2.65^{\mathrm{c}}$ \\
\hline $\mathrm{N}_{2}$ & $148.9^{\mathrm{b}}$ & $88.44^{\mathrm{a}}$ & $116.6^{\mathrm{b}}$ & $88.81^{\mathrm{a}}$ & $251.8^{\mathrm{a}}$ & $9.66^{\mathrm{a}}$ & $201.1^{\mathrm{b}}$ & $44.28^{\mathrm{b}}$ & $2.88^{\mathrm{a}}$ & $3.56^{\mathrm{b}}$ \\
\hline $\mathrm{N}_{3}$ & $163.2^{\mathrm{a}}$ & $90.61^{\mathrm{a}}$ & $124.3^{\mathrm{a}}$ & $90.22^{\mathrm{a}}$ & $264.9^{\mathrm{a}}$ & $10.32^{\mathrm{a}}$ & $220.0^{\mathrm{a}}$ & $46.40^{\mathrm{a}}$ & $2.90^{\mathrm{a}}$ & $4.19^{\mathrm{a}}$ \\
\hline F test & $* *$ & $* *$ & $* *$ & $* *$ & $* *$ & $* *$ & $* *$ & $* *$ & $* *$ & $* *$ \\
\hline $\operatorname{LSD}_{(0.05)}$ & 10.23 & 3.79 & 2.89 & 1.94 & 19.4 & 0.89 & 17.28 & 1.67 & 0.280 & 4.47 \\
\hline $\operatorname{SEm}( \pm)$ & 157.3 & 21.5 & 12.49 & 5.64 & 565.9 & 1.19 & 449.0 & 4.21 & 0.12 & 0.33 \\
\hline \multicolumn{11}{|l|}{ Genotypes } \\
\hline $\begin{array}{l}\text { BL } 3623 \\
\text { (V1) }\end{array}$ & 145.8 & $83.67^{b}$ & $113.4^{\mathrm{bc}}$ & 85.65 & 208.5 & 9.11 & 174.1 & 44.23 & 2.47 & 3.24 \\
\hline $\begin{array}{l}\text { BL } 3629 \\
\text { (V2) }\end{array}$ & 148.1 & $83.5^{\mathrm{b}}$ & $115.5^{\mathrm{abc}}$ & 85.14 & 202.2 & 9.37 & 186.3 & 42.16 & 2.41 & 2.96 \\
\hline $\begin{array}{l}\text { BL } 3872 \\
\text { (V3) }\end{array}$ & 146.6 & $87.92^{\mathrm{a}}$ & $118.2^{\mathrm{ab}}$ & 82.52 & 204.3 & 9.41 & 190.3 & 42.83 & 2.48 & 3.18 \\
\hline $\begin{array}{l}\text { NL } 1008 \\
\text { (V4) }\end{array}$ & 144.0 & $87.83^{\mathrm{a}}$ & $116.4^{\mathrm{abc}}$ & 87.14 & 207.8 & 9.72 & 175.8 & 42.07 & 2.33 & 3.25 \\
\hline $\begin{array}{l}\text { NL } 1055 \\
\text { (V5) }\end{array}$ & 148.1 & $85.75^{\mathrm{ab}}$ & $120.0^{\mathrm{a}}$ & 86.75 & 209.2 & 9.31 & 186.8 & 42.13 & 2.40 & 3.14 \\
\hline Vijay (V6) & 143.8 & $85.83^{\mathrm{ab}}$ & $112.3^{\mathrm{c}}$ & 87.02 & 213.0 & 9.75 & 194.3 & 45.37 & 2.52 & 3.26 \\
\hline F test & NS & $*$ & $*$ & NS & NS & NS & NS & NS & NS & NS \\
\hline $\operatorname{LSD}_{(0.05)}$ & - & 2.50 & 5.80 & - & - & - & - & - & - & - \\
\hline $\operatorname{SEm}( \pm)$ & 107.1 & 9.17 & 49.47 & 3.07 & 67.16 & 0.44 & 355 & 7.74 & 0.43 & 0.15 \\
\hline $\mathrm{CV} \%$ & 7.09 & 3.53 & 6.67 & 7.92 & 8.47 & 7.04 & 10.21 & 6.52 & 8.53 & 11.99 \\
\hline Grand mean & 146.04 & 85.75 & 115.96 & 86.37 & 207.49 & 9.44 & 184.58 & 42.63 & 2.44 & 3.17 \\
\hline $\begin{array}{l}\text { Interaction } \\
\mathrm{NxV}\end{array}$ & NS & NS & NS & NS & NS & NS & NS & NS & NS & NS \\
\hline
\end{tabular}


Emergence count $\mathrm{m}^{-2}$ of wheat genotypes had significantly $(\mathrm{p} \leq 0.05)$ affected in both the years by different levels of $\mathrm{N}$ applied. Results indicated that the highest emergence $\mathrm{m}^{-2}, 163.2$ in the year 2013 and 164.8 in the year 2014 were recorded when the crop was fertilized with $150 \mathrm{~kg} \mathrm{~N} \mathrm{ha}^{-1}$ (Table 3 and 4). In both the years days to heading (DTH) and days to maturity (DTM) were significantly (p $\leq 0.05$ ) affected by different $\mathrm{N}$ levels (Table 3 and 4). The maximum plant height $\left(90.22 \mathrm{~cm}\right.$ ) was resulted in treatment N3 $\left(150 \mathrm{~kg} \mathrm{~N} \mathrm{ha}^{-1}\right)$, but was statistically $(\mathrm{p} \leq 0.05)$ similar $(88.81 \mathrm{~cm})$ to $\mathrm{N} 2\left(100 \mathrm{~kg} \mathrm{~N} \mathrm{ha}^{-1}\right)$ in 2013 .

In 2014, the application of $150 \mathrm{~kg} \mathrm{~N} \mathrm{ha}^{-1}$ gave also the highest plant height $(92.43 \mathrm{~cm})$ in same treatment. However, average plant height was lower in the year $2014(85.30)$ as compared to previous year $(86.37 \mathrm{~cm})$ (Table 3 and 4$)$. The $\mathrm{N}$ treatments significantly $(\mathrm{p} \leq 0.05)$ increased the numbers of productive tillers $\mathrm{m}^{-2}$ than in control in both the years. Application of $150 \mathrm{~kg} \mathrm{~N}^{-1}$ produced the maximum numbers of productive tillers $\left(264.9 \mathrm{~m}^{-2}\right)$ and $\left(273.6 \mathrm{~m}^{-2}\right)$ in 2013 and 2014 , respectively. The check variety, Vijay produced the maximum numbers of productive tillers in both the years with $213 \mathrm{~m}^{-2}$ and $224.6 \mathrm{~m}^{-2}$. This trend was attributed to comparatively better growth due to higher fertilizer application. Spike length increased with increasing level of $\mathrm{N} ; 100 \mathrm{~kg} \mathrm{~N} \mathrm{ha}^{-1}$ and $150 \mathrm{~kg} \mathrm{~N}^{-1} \mathrm{produced}^{-1}$ statistically similar result in 2013 (Table 3 and 4). However, application of $150 \mathrm{~kg} \mathrm{~N} \mathrm{ha}^{-1}$ resulted the maximum spike length (11.24 cm) followed by $10.09 \mathrm{~cm}$ in case of $\mathrm{N}_{3}\left(100 \mathrm{~kg} \mathrm{~N} \mathrm{ha}^{-1}\right)$ in 2014 . The maximum number of spikes $\mathrm{m}^{-2}$ was produced by the application of 150 $\mathrm{kg} \mathrm{N} \mathrm{ha}^{-1}$ in both the years i.e. $220 \mathrm{~m}^{-2}$ and $249 \mathrm{~m}^{-2}$ in 2013 and 2014, respectively.

The highest values of 1000-grain weight $46.40 \mathrm{~g}$ and $46.90 \mathrm{~g}$ were achieved in 2013 and 2014 respectively, both with the application of $150 \mathrm{~kg} \mathrm{~N} \mathrm{ha}^{-1}$. Hence, the yield contributing characters viz. productive tillers $\mathrm{m}^{-2}$, spike length $(\mathrm{cm})$, spikes $\mathrm{m}^{-2}$ and test weight $(\mathrm{g})$ increase significantly $(\mathrm{p} \leq 0.05)$ with every increase in the dose of $\mathrm{N}$ up to $150 \mathrm{~kg} \mathrm{~N} \mathrm{ha}^{-1}$ in both the years (Table 3 and 4 ). Grain yield response varied with the season and yield was higher in 2014 seasons than 2013. The average increment of grain yield in 2014 compared to 2013 was $5.52 \%$ at $150 \mathrm{~kg} \mathrm{~N} \mathrm{ha}^{-1}$. In both the years, Vijay resulted the highest grain yield; $3.12 \mathrm{tha}^{-1}$ in 2013 with the application of $100 \mathrm{~kg} \mathrm{~N} \mathrm{ha}^{-1}$ and $3.23 \mathrm{tha}^{-1}$ in 2014 by $150 \mathrm{~kg} \mathrm{~N} h^{-1}$ followed by BL 3872 in $2013\left(3.01 \mathrm{t} \mathrm{ha}^{-1}\right)$ and BL 3623 in 2014 ( $3.16 \mathrm{t} \mathrm{ha}^{-1}$ ), both with the application of $150 \mathrm{~kg} \mathrm{~N} \mathrm{ha}^{-1}$ (Table 3 and 4). In both the years, $\mathrm{N}_{2}\left(100 \mathrm{~kg} \mathrm{~N} \mathrm{ha}^{-1}\right)$ and N $\mathrm{N}_{3}\left(150 \mathrm{~kg} \mathrm{~N} \mathrm{ha}^{-1}\right)$ produced statistically similar results (Table 3 and 4). The obtained grain yield in wheat might be the result of effective tillers, number of spikes $\mathrm{m}^{-2}$ and grain weight. The highest straw yield $\left(4.19 \mathrm{t} \mathrm{ha}^{-1}\right)$ was obtained from application of $150 \mathrm{~kg} \mathrm{~N}^{-1} \mathrm{followed} \mathrm{by} 3.56 \mathrm{t}$ ha $^{-1}$ in case of $100 \mathrm{~kg} \mathrm{~N} \mathrm{ha}^{-1}$ in 2013. Similarly, the maximum straw yield (3.66 tha $\mathrm{t}^{-1}$ ) was obtained from $150 \mathrm{~kg} \mathrm{~N} \mathrm{ha}^{-1}$ ) in 2014 (Table 4$)$.

Table 4. Growth, yield and yield components of wheat genotypes under different levels of nitrogen in the year 2014 at RARS, Tarahara, Nepal

\begin{tabular}{|c|c|c|c|c|c|c|c|c|c|c|}
\hline Treatments & $\begin{array}{l}\text { Emergence } \\
\text { count } \mathrm{m}^{-2}\end{array}$ & $\begin{array}{l}\text { Days to } \\
\text { heading }\end{array}$ & $\begin{array}{l}\text { Days to } \\
\text { maturity }\end{array}$ & $\begin{array}{l}\text { Plant } \\
\text { height } \\
(\mathrm{cm})\end{array}$ & $\begin{array}{l}\text { Productive } \\
\text { tillers } \mathrm{m}^{-2}\end{array}$ & $\begin{array}{l}\text { Spike } \\
\text { length } \\
(\mathrm{cm})\end{array}$ & $\begin{array}{l}\text { Spikes } \\
\mathrm{m}^{-2}\end{array}$ & Test weight (g) & $\begin{array}{l}\text { Grain yield } \\
\left(\mathrm{t} \mathrm{ha}^{-1}\right)\end{array}$ & $\begin{array}{l}\text { Straw } \\
\text { yield (t } \\
\left.\mathrm{ha}^{-1}\right)\end{array}$ \\
\hline \multicolumn{11}{|l|}{ N levels } \\
\hline \multicolumn{11}{|l|}{$\mathrm{N}_{0}$} \\
\hline & $137.8^{c}$ & $81.17^{b}$ & $108.4^{\mathrm{d}}$ & $79.53^{c}$ & $146.6^{\mathrm{d}}$ & $8.370^{c}$ & $151.7^{\mathrm{c}}$ & $39.16^{\mathrm{d}}$ & $1.75^{\mathrm{c}}$ & $2.56^{c}$ \\
\hline $\mathrm{N}_{1}$ & $147.6^{\mathrm{bc}}$ & $82.61^{b}$ & $116.5^{\mathrm{c}}$ & $85.93^{b c}$ & $165.5^{\mathrm{c}}$ & $9.479^{b}$ & $172.6^{\mathrm{c}}$ & $41.85^{\mathrm{c}}$ & $2.53^{\mathrm{b}}$ & $2.74^{\mathrm{c}}$ \\
\hline $\mathrm{N}_{2}$ & $159.0^{\mathrm{ab}}$ & $86.89^{a}$ & $121.1^{\mathrm{b}}$ & $86.61^{b}$ & $242.9^{\mathrm{b}}$ & $10.09^{\mathrm{b}}$ & $215.1^{\mathrm{b}}$ & $44.79^{b}$ & $2.94^{\mathrm{a}}$ & $3.38^{\mathrm{b}}$ \\
\hline $\mathrm{N}_{3}$ & $164.8^{\mathrm{a}}$ & $89.83^{\mathrm{a}}$ & $131.2^{\mathrm{a}}$ & $92.43^{\mathrm{a}}$ & $273.6^{\mathrm{a}}$ & $11.24^{\mathrm{a}}$ & $249.9^{\mathrm{a}}$ & $46.90^{\mathrm{a}}$ & $3.06^{\mathrm{a}}$ & $3.66^{\mathrm{a}}$ \\
\hline F test & $* *$ & $* *$ & $* *$ & $* *$ & $* *$ & $* *$ & $* *$ & $* *$ & $* *$ & $* *$ \\
\hline $\operatorname{LSD}_{(0.05)}$ & 12.35 & 3.81 & 2.88 & 14.16 & 16.81 & 0.63 & 30.34 & 1.19 & 0.13 & 0.28 \\
\hline $\operatorname{SEm}( \pm)$ & 229.4 & 21.86 & 12.49 & 301.40 & 425.0 & 0.59 & 1383 & 2.14 & 0.03 & 0.12 \\
\hline \multicolumn{11}{|l|}{ Genotypes } \\
\hline $\begin{array}{l}\text { BL } 3623 \\
(\mathrm{~V} 1)\end{array}$ & 156.2 & $82.75^{b}$ & $118.2^{b c}$ & 84.46 & 209.6 & 9.52 & 178.6 & 44.28 & 2.60 & 3.01 \\
\hline $\begin{array}{l}\text { BL } 3629 \\
\text { (V2) }\end{array}$ & 146.3 & $83.08^{b}$ & $113.6^{c}$ & 83.68 & 201.0 & 9.56 & 200.3 & 42.89 & 2.64 & 2.84 \\
\hline $\begin{array}{l}\text { BL } 3872 \\
\text { (V3) }\end{array}$ & 147.7 & $89.82^{a}$ & $126.5^{\mathrm{a}}$ & 86.29 & 204.6 & 9.90 & 197.8 & 42.67 & 2.52 & 3.34 \\
\hline $\begin{array}{l}\text { NL } 1008 \\
\text { (V4) }\end{array}$ & 150.6 & $85.75^{\mathrm{ab}}$ & $118.2^{\mathrm{bc}}$ & 85.16 & 206.2 & 9.99 & 197.1 & 43.17 & 2.49 & 3.15 \\
\hline $\begin{array}{l}\text { NL } 1055 \\
\text { (V5) }\end{array}$ & 155.9 & $84.67^{b}$ & $120.8^{\mathrm{ab}}$ & 85.39 & 198.8 & 9.76 & 184.3 & 44.19 & 2.42 & 3.28 \\
\hline Vijay (V6) & 155.6 & $85.58^{\mathrm{ab}}$ & $118.6^{\mathrm{bc}}$ & 86.84 & 224.6 & 10.03 & 212.7 & 42.72 & 2.74 & 3.08 \\
\hline F test & NS & $*$ & $*$ & NS & NS & NS & NS & NS & $\mathrm{NS}$ & $\mathrm{NS}$ \\
\hline $\operatorname{LSD}_{(0.05)}$ & - & 3.66 & 6.49 & - & - & - & - & - & - & - \\
\hline $\operatorname{SEm}( \pm)$ & 85.13 & 19.67 & 61.77 & 9.17 & 464.7 & 0.48 & 687.8 & 9.47 & 0.09 & 0.13 \\
\hline CV \% & 6.07 & 5.21 & 6.59 & 5.02 & 10.41 & 7.06 & 13.29 & 7.13 & 11.47 & 12.32 \\
\hline Grand mean & 152.03 & 85.13 & 119.29 & 85.30 & 207.125 & 9.79 & 197.33 & 43.18 & 2.59 & 3.09 \\
\hline \multicolumn{11}{|l|}{ Interaction } \\
\hline $\mathrm{NxV}$ & NS & NS & NS & NS & NS & NS & NS & NS & NS & NS \\
\hline
\end{tabular}




\section{DISCUSSION}

The present data were supportive for the evaluation of nutritional demand and yield potential of different pipeline wheat varieties for $\mathrm{N}$ fertilization. It was shown that higher performance of yield components and ultimate grain yield was associated with higher $\mathrm{N}$ fertilization levels (Table 4). The significant $(\mathrm{P} \leq 0.05)$ enhancement of plant height in all treatments over the control $\left(\mathrm{N}_{0}\right)$ in both the years can be credited to higher dose of $\mathrm{N}$, which greatly helps the plant to expose its potential to grow potentially. The increasing dose of $\mathrm{N}$ result the linear increment in spike length in both years for all pipeline varieties. These results are in conformity with those of (Rai and Khadka 2009) who observed maximum spike length under fertilization of $100 \mathrm{~kg} \mathrm{~N} \mathrm{ha}^{-1}$ as compared to control and $50 \mathrm{~kg} \mathrm{~N} \mathrm{ha}^{-1}$ in their long term experiment in Khumaltar. Higher test weight with increasing $\mathrm{N}$ levels might be due to supply of more $\mathrm{N}$ and higher production of photosynthates (Naseri et al 2010) that showed linearly increased test weight due to increasing levels of N application (Figure 4).

Hence, the yield contributing characters viz productive tillers $\mathrm{m}^{-2}$, spike length $(\mathrm{cm})$, spikes $\mathrm{m}^{-2}$ and test weight $(\mathrm{g})$ increase significantly $(\mathrm{p} \leq 0.05)$ with every increase in the dose of $\mathrm{N}$ up to $150 \mathrm{~kg} \mathrm{~N} \mathrm{ha}^{-1}$ in both the years (Table 3 and 4). This tendency was attributed to comparatively better growth due to higher fertilizer application. The poor growth of the wheat plants and the consequential lower grain yield in control $\left(\mathrm{N}_{0}\right)$ ) plots may be due to competition for $\mathrm{N}$ from the soil and starved conditions. Meteorological conditions for the two years were more suitable to the emergence and survival of tillers and further tillering and development of spikes at higher nitrogen levels (Figure 2 and 3).

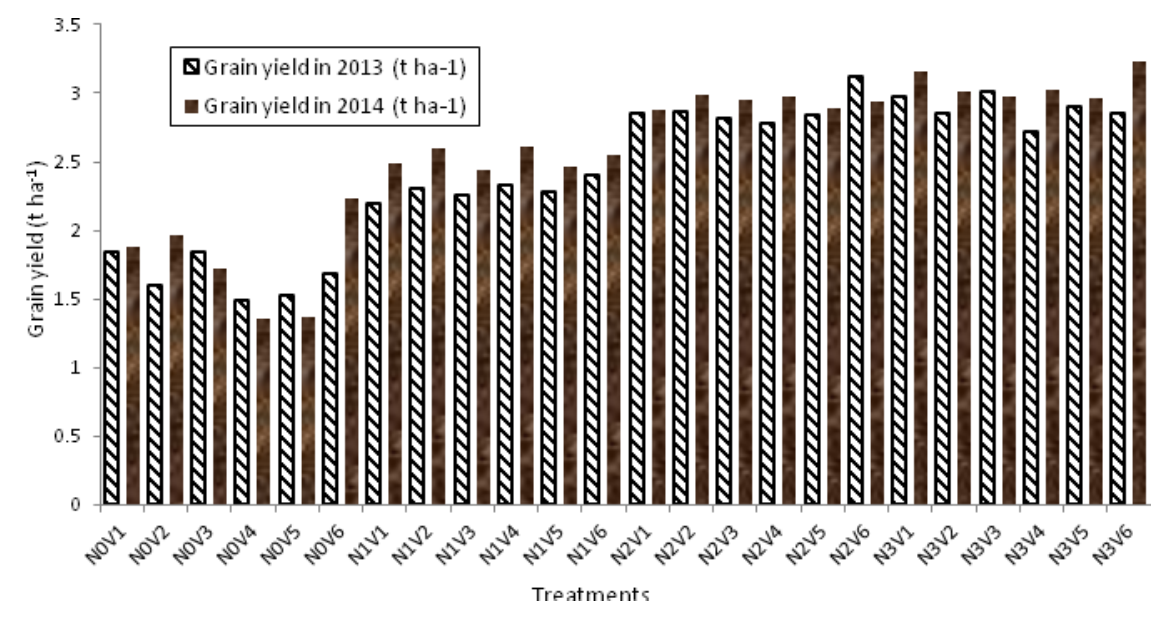

Figure 3. Grain yield of wheat genotypes from different treatments in years 2013 and 2014.

Probably the meteorological suitability enhanced competition for nutrients and photo assimilates making the varieties more responsive to the applied fertilizers. A greater response to $\mathrm{N}$ fertilization is obvious when a meteorological condition remains favorable, especially rainfall were not the limiting factors (Figure $2 \mathrm{~A}, \mathrm{~B}$ ). The responsiveness of the tested varieties to the applied fertilizers should be studied further before it reached to farmers' field.

Benis et al (1994) argued that the yield response of wheat to nitrogen depends on factors such as climate, soil and cultivar. Identification of correlations between meteorological variables and grain yield for such pipelines can be another subject of study.
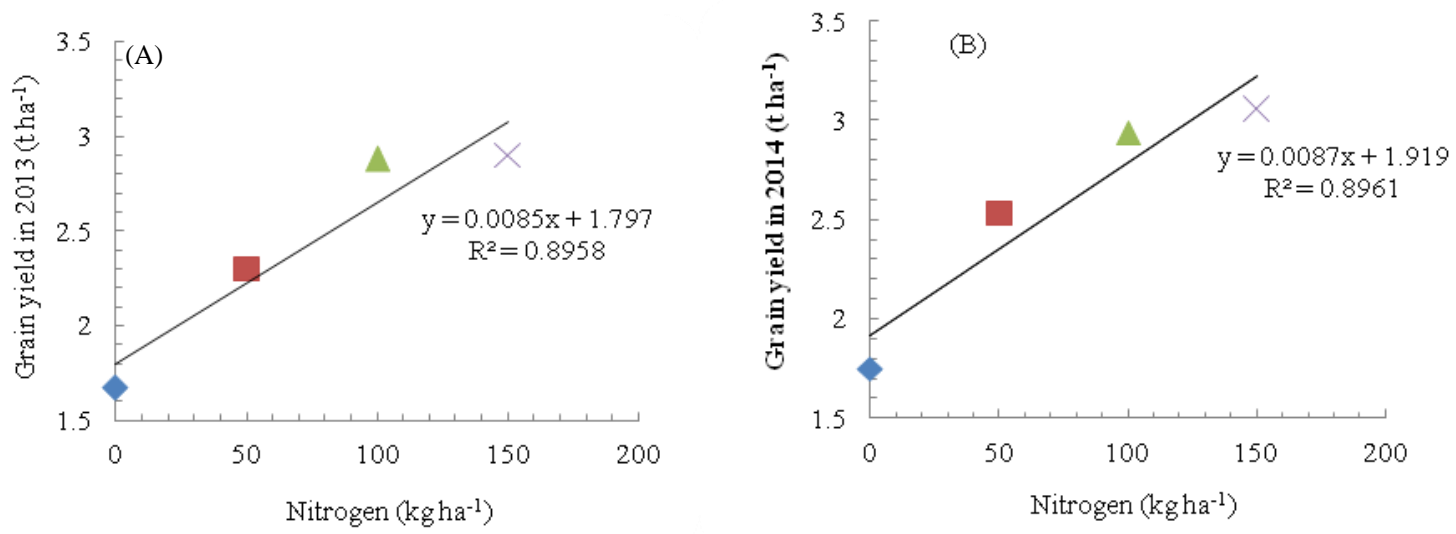

Figure 4. Grain yield of wheat genotypes to various N levels in 2013 (A) and 2014 (B). 
Vol. 2:9-13, December 2016

DOI: http://dx.doi.org/10.3126/jnarc.v2i0.16115

\section{CONCLUSION}

The study showed that all the wheat genotypes responded well up to the levels of $150 \mathrm{~kg} \mathrm{~N}^{-1}$ regarding yield and yield attributing characters. The performance of Vijay with respect to productive tillers $\mathrm{m}^{-2}$, grain yield and straw yield with combination of $150 \mathrm{~kg} \mathrm{~N}$ ha

${ }^{1}$ was the best. With well cultural management practices application of $100 \mathrm{~kg} \mathrm{~N} \mathrm{ha}^{-1}$ can give good grain yield of wheat.

\section{ACKNOWLEDGEMENT}

The authors express their gratitude to the government of Nepal, Nepal Agricultural Research Council (NARC) for supporting this study. This is an outcome of Project 40370004 funded by NARC. The authors are thankful to RARS (Tarhara) and National Wheat Research Program, Bhairahawa, Rupandehi for providing seeds, accessories and other supports.

\section{REFERENCES}

Barraclough PB, JR Howarth, J Jones, R Lopez-Bellido, S Parmar, CE Shepherd and MJ Hawkesford. 2010. Nitrogen efficiency of wheat: genotypic and environmental variation and prospects for improvement. European Journal of Agronomy 33:1-11.

Benin G, E Bornhofen, E Beche, E Stefani Pagliosa, C Lemes da Silva and C Pinnow. 2012 Agronomic performance of wheat cultivars in response to nitrogen fertilization levels. Acta Scientiarum 34(3):275-283.

Bhattarai R, B Chaudhary, DB Thapa, RR Puri, RN Chaudhary, B Sapkota, KB, SR Shrestha and SP Adhikari. 2015. Wheat yield interaction with sowing dates of Seeding in Eastern Mid Hills of Nepal, Journal of Nepal Agricultural Research Council, 1:33-36,

Bouyoucos GJ. 1962. Hydrometer method improved for making particle size analyses of soils. Agronomy Journal 54(5):464-465.

Bremner J M and CS Mulvaney. 1982. Nitrogen total. In: A. L. Page (ed.), Methods of soil analysis. Agron. No. 9, Part 2: Chemical and microbiological properties. $2^{\text {nd }}$ edition. Am. Soc. Agron., Madison, W I, USA. pp.595-624.

Camara KM, WA Payne and PE Rasmussen. 2003. Long term effects of tillage, nitrogen, and rainfall on winter wheat yields in the Pacific Northwest. Agron. J. 95:828-835.

Campbell CA, RP Zenner, F Selles, BG McConkey and FB Dyck. 1993. Nitrogen management for spring wheat grown annually on zero tillage: yields and nitrogen use efficiency. Agron. J. 85(1):107-114.

DADO 2012/13. Annual Agriculture Development Program and Statistical Book. District Agriculture Development Office, Inaruwa, Sunsari. 67

Heineman A B, LF Stone, DD Agostinho and AD Canovas. 2006. Solar radiation use efficiency on the wheat grain yield as a function of nitrogen fertilizer. Rev. bras. Eng. Agric. Ambient 10:352-356.

Jackson M L. 1967. Handling soil samples in the laboratory. In: Soil chemical analysis. Prentice hall of India, Pvt. Ltd., New Delhi 2: 30-37.

Jackson ML. 197s3. Soil Chemical Analysis. Pentice Hall of India Pvt. Ltd., New Delhi.

Joshi BK, Thapa DB, Bhatta MR .2015. Genetic parameters of common wheat, Journal of Nepal Agricultural Research Council,1:9-13.

Ma BL, TY Wu, N Tremblay, W Deen, NB Mclaughlin, MJ Morrison and G Stewart. 2010. On-farm assessment of the amount and timing of nitrogen fertilizer on ammonia volatilization. Agronomy Journal 102:134-144.

MoAD. 2012/13. Crop situation update. A joint assessment of 2012/13 winter and 2013/14 summer crops outlook, MoAD, Nepal. 18pp.

MoAD. 2013. Statistical Information on Nepalese Agriculture. 2013. Agribusiness Promotion and Statistics Division, Statistics Section, Ministry of Agricultural Development, Government of Nepal, Singh Durbar, Kathmandu, Nepal.

Naseri R, A Mirzaei, R Soleimani and E Nazarbeygi. 2010. Response of bread wheat to nitrogen application in calcareous soils of Western Iran. Am-Eurasian J. of Agric. Env. Sci. 9(1):79-85.

NWRP. 2012. Executive summary. In: Annual report-2012. National Wheat Research Program (NWRP)- Nepal Agricultural Research Council, Bhairhawa- Rupandehi. pp. 6-11.

Olsen SR, CV Cole and LA Dean. 1954. Estimation of available phosphorus in soil by extraction with sodium carbonate. In: Method of soil analysis, Part 2. (CA Black, ed) American Soc. Agron. Inc, Medison, USA. pp. 1044-1046.

Podolska G. 2014. Technological quality of winter wheat depending on nitrogen applications. In: Proceedings of the $18^{\text {th }}$ Nitrogen WorkshopThe nitrogen challenge: building a blueprint for nitrogen use efficiency and food security (CMdS Cordovil, ed). $30^{\text {th }}$ June- $3^{\text {rd }}$ July 2014 , Lisbon, Portugal. 175 p.

Rai S K and Y G Khadka. 2009. Wheat production under long term application of inorganic and organic fertilizers in rice-wheat system under rainfed conditions. Nepal Agric. Res. J. 9:123-131.

Raun WR and GV Johnson. 1999. Improving nitrogen use efficiency for cereal production. Agronomy Journal 91:357-363.

Riley WJ, I Ortiz-Monasterio and PA Matson. 2001. Nitrogen leaching and soil nitrate, nitrite, and Wheat responsiveness to nitrogen. Nutrient Cycling in Agroecosystems 61:223-236.

Rusell K, DV Sanford and C Lee. 2014. Genotype specific management for nitrogen use efficiency in Kentucky soft red winter wheat. Aspects of Applied Biology 25:227-287.

Salvagiotti F and DJ Miralles. 2008. Radiation interception, biomass production and grain yield as affected by the interaction of nitrogen and sulfur fertilization in wheat. Europ. J. Agron. 28:282-290.

Sarwar M, G Jilani, E Rafique, ME Akhtar and AN Chaudhry. 2012. Impact of integrated nutrient management on yield and nutrient uptake by maize under rain-fed conditions. Pak. J. Nutr. 11:27-33.

Spiertz J, D Vos and L Hole. 1984. The role of nitrogen in the yield formation of cereals, especially of winter wheat. In: the Proceedings of Cereal Production, Royal Dublin Society, Bultworths 5(3):34-65.

Wagen M R, FC Oad and KS Nenwani. 2003. Quantitative and qualitative characteristics of wheat crop under various sources and methods of nitrogenous fertilizer application. Asian J. of Plant. Sci. 2(9):683-687.

Walkley AJ and IA Black. 1934. Estimation of soil organic carbon by the chromic acid titration method. Soil Sci. 37(1):29-38. 